\title{
ASPEK PAJAK DAN DAMPAK \\ KETERLAMBATAN KEPEMILIKAN NPWP PRIBADI DENGAN \\ DIBERLAKUKANNYA UNDANG-UNDANG NO. 28 TAHUN 2007 DAN \\ UNDANG-UNDANG NO. 36 TAHUN 2008
}

\author{
Jeni Susyanti \\ Fakultas Ekonomi Universitas Islam Malang \\ Jl. MT Haryono 193 Malang. Telp 0341-571996 \\ Kantor Konsultan Pajak AD Consulting \\ J1. Kapuas 22 Malang, Tilp.0341-494761, 498993
}

\begin{abstract}
The society's obligation to support the government continuity is through the tax. Having NPWP is everyone's obligation, whether he is individual who conducts business activities, does free work, or works as employee. By the implementation of Undang Undang No. 28 tahun 2007 regarding the General Rules and Tax Explanation and Undang-undang No.36 tahun 2008 regarding the Income Tax, there is a discrimination of tax applied to an individual who has NPWP against those who doesn't.
\end{abstract}

Key words : NPWP (Tax Registration Number), WPOP (Individual Tax Payers)

Pajak bagi sebuah Negara merupakan suatu kemutlakan. Tanpa adanya pemasukan pajak, Negara tidak bisa berbuat apa-apa. Semakin maju sebuah Negara, kesadaran akan pentingnya membayar pajak semakin tinggi. Di Indonesia, harapan yang tinggi diletakkan pada perolehan penerimaan pajak yang cukup tinggi untuk dapat mengurangi defisit anggaran.

Menurut kamus Webster, pajak (tax) didefinisikan sebagai a contribution for the support of a government required of persons, groups, or businesses within the domain of that government; atau a fee or dues levied on the members of an organization to meet its expenses. Atau dapat dikatakan bahwa pajak merupakan "suatu kontribusi wajib dari masyarakat untuk mendukung keberlangsungan sebuah pemerintahan dalam masyarakat tersebut." Kontribusi ini pada umumnya adalah persentase tertentu pendapatan (earnings) masyarakat tersebut.

Pemungutan pajak bisa dilakukan dengan dua cara, yaitu self assessment dan official assessment. Self assessment adalah sistem pemungutan pajak, di mana 
wajib pajak menentukan sendiri jumlah pajak yang terhutang. Dalam sistem, ini wajib pajak diberi kepercayaan untuk menghitung sendiri, membayar, dan melaporkan jumlah pajak yang terutang. Official assessment adalah sistem pemungutan pajak, di mana aparat perpajakan menentukan sendiri jumlah pajak yang terhutang.

Sesuai ketentuan pasal 2 Undang-undang Nomor 28 Tahun 2007 (UU KUP) beserta penjelasannya, orang pribadi wajib ber-NPWP apabila telah memenuhi syarat subyektif dan obyektif. Yang dimaksud dengan syarat subyektif disini adalah persyaratan subyektif sebagaimana disebutkan dalam pasal 2 Undang-undang Nomor 7 tahun 1983 sebagaimana telah dirubah dengan Undang-undang Nomor 36 tahun 2008 (UU PPh). Dalam hal ini orang pribadi dianggap memenuhi syarat subyektif bila berstatus sebagai subyek pajak Indonesia (Subyek Pajak Dalam Negeri). Sedangkan syarat Obyektif disini merupakan persyaratan bagi subyek pajak yang menerima atau memperoleh penghasilan atau diwajibkan untuk melakukan pemotongan/ pemungutan sesuai dengan ketentuan Undang-undang Pajak Penghasilan. Sehingga syarat obyektif dapat dilihat dari dua sudut pandang, yaitu dari sisi penerima penghasilan dan dari sisi pemberi penghasilan.

Dari sisi kewajiban ber-NPWP untuk orang pribadi dua syarat tersebut harus dipenuhi. Kemudian mengenai saatnya ber-NPWP bagi orang pribadi, diatur dalam Peraturan Menteri Keuangan Nomor: 20/PMK.03/2008. Dalam peraturan tersebut dinyatakan bahwa bagi orang pribadi yang melakukan kegiatan usaha dan atau pekerjaan bebas wajib ber-NPWP paling lambat sebulan setelah usaha mulai dijalankan. Sedangkan untuk orang pribadi yang tidak melakukan kegiatan usaha atau pekerjaan bebas wajib ber-NPWP apabila penghasilan yang diterimanya dalam satu bulan yang disetahunkan telah melebihi batasan Penghasilan Tidak Kena Pajak (PTKP). Paling lambat orang pribadi ini harus sudah ber-NPWP akhir bulan berikutnya. 


\section{KEWAJIBAN WAJIB PAJAK}

Berdasarkan undang-undang no 6 tahun 1983 tentang ketentuan umum dan tatacara perpajakan, sebagaimana terakhir telah diubah dengan undangundang no 28 tahun 2007, terdapat kewajiban wajib pajak sebagai berikut:

\section{1) Mendaftarkan diri ke KPP untuk memperoleh NPWP.}

Nomor Pokok Wajib Pajak (NPWP) adalah suatu sarana dalam administrasi perpajakan yang dipergunakan sebagai tanda pengenal diri atau identitas Wajib Pajak, oleh karena itu kepada setiap Wajib Pajak hanya diberikan satu Nomor Pokok Wajib Pajak. Selain itu, Nomor Pokok Wajib Pajak juga dipergunakan untuk menjaga ketertiban dalam pembayaran pajak dan dalam pengawasan administrasi perpajakan. Dalam hal berhubungan dengan dokumen perpajakan, Wajib Pajak diwajibkan mencantumkan Nomor Pokok Wajib Pajak yang dimilikinya.

2) Wajib melaporkan usahanya untuk dikukuhkan menjadi Pengusaha Kena Pajak.

Setiap Wajib Pajak sebagai Pengusaha yang memenuhi syarat untuk dikenakan pajak berdasarkan Undang-undang PPN, wajib melaporkan usahanya untuk dikukuhkan menjadi Pengusaha Kena Pajak. Fungsi pengukuhan Pengusaha Kena Pajak selain dipergunakan untuk mengetahui identitas Pengusaha Kena Pajak yang sebenarnya, juga berguna untuk melaksanakan hak dan kewajiban di bidang PPN dan Pajak Penjualan Atas Barang Mewah (PPn BM) serta untuk pengawasan administrasi perpajakan.

3) Mengambil sendiri Surat Pemberitahuan di tempat yang ditetapkan oleh Direktur Jenderal Pajak.

Dalam rangka pelayanan dan kemudahan bagi Wajib Pajak, formulir Surat Pemberitahuan disediakan pada kantor-kantor di lingkungan DJP dan tempat-tempat lain yang ditentukan oleh Direktur Jenderal Pajak yang diperkirakan mudah terjangkau oleh Wajib Pajak. 
4) Wajib Pajak wajib mengisi dan menyampaikan Surat Pemberitahuan dengan benar, lengkap, jelas, dan menandatanganinya.

Setiap Wajib Pajak wajib mengisi Surat Pemberitahuan dalam bahasa Indonesia dengan menggunakan huruf Latin, angka Arab, satuan mata uang Rupiah, dan menandatangani serta menyampaikannya ke kantor pelayanan pajak tempat Wajib Pajak terdaftar atau dikukuhkan. Bagi Wajib Pajak yang telah mendapat izin Menteri Keuangan untuk menyelenggarakan pembukuan dengan menggunakan bahasa asing dan mata uang selain Rupiah, wajib menyampaikan Surat Pemberitahuan dalam bahasa Indonesia dan mata uang selain Rupiah yang diizinkan.

\section{5) Wajib membayar atau menyetor pajak yang terutang di kas negara}

Setiap Wajib Pajak dapat membayar atau menyetor melalui Kantor Pos dan atau Bank Persepsi dengan menggunakan Surat Setoran Pajak (SSP). Setiap Wajib Pajak wajib membayar pajak yang terutang berdasarkan ketentuan peraturan perundang-undangan perpajakan, dengan tidak menggantungkan pada adanya surat ketetapan pajak

\section{6) Wajib menyelenggarakan pembukuan atau pencatatan.}

Bagi Wajib Pajak orang pribadi yang melakukan kegiatan usaha atau pekerjaan bebas dan Wajib Pajak badan di Indonesia diwajibkan untuk menyelenggarakan pembukuan. Dikecualikan dari kewajiban pembukuan, tetapi diwajibkan melakukan pencatatan bagi Wajib Pajak orang pribadi yang melakukan kegiatan usaha atau pekerjaan bebas yang menurut ketentuan peraturan perundang-undangan perpajakan diperbolehkan menghitung penghasilan neto dengan menggunakan Norma Penghitungan Penghasilan Neto dan Wajib Pajak orang pribadi yang tidak melakukan kegiatan usaha atau pekerjaan bebas. Pembukuan dan dokumen-dokumen yang berhubungan dengan kegiatan usaha harus disimpan oleh wajib pajak selama 10 (sepuluh) tahun. Karena selama jangka waktu tersebut DJP masih dapat melakukan pemeriksaan (PER-4/PJ/2009). 


\section{7) Dalam hal terjadi pemeriksaan pajak, Wajib Pajak wajib :}

- Memperlihatkan dan atau meminjamkan buku atau catatan, dokumen yang menjadi dasarnya dan dokumen lain yang berhubungan dengan penghasilan yang diperoleh, kegiatan usaha, pekerjaan bebas Wajib Pajak, atau objek yang terutang

pajak;

- Memberikan kesempatan untuk memasuki tempat atau ruang yang dipandang perlu dan memberi bantuan guna kelancaran pemeriksaan;

- Memberikan keterangan yang diperlukan.

\section{HAK WAJIB PAJAK}

Berdasarkan undang-undang no 6 tahun 1983 tentang ketentuan umum dan tatacara perpajakan, sebagaimana terakhir telah diubah dengan undangundang no 28 tahun 2007, terdapat hak wajib pajak sebagai berikut:

1. Wajib Pajak berhak untuk menerima tanda bukti pelaporan SPT.

Untuk Surat Pemberitahuan yang disampaikan dengan pos tercatat melalui kantor pos dan giro, maka tanggal pegiriman dianggap sebagai tanggal penerimaan.

2. Wajib Pajak berhak untuk mengajukan permohonan penundaan penyampaian SPT.

Apabila Wajib Pajak ternyata tidak dapat menyampaikan atau menyiapkan laporan keuangan tahunan atau neraca perusahaan beserta laporan laba rugi dalam jangka waktu yang telah ditetapkan karena luasnya kegiatan usaha dan masalah-masalah teknis penyusunan laporan keuangan, sulit untuk memenuhi batas waktu penyelesaian dan memerlukan kelonggaran dari batas waktu yang telah ditentukan, Wajib Pajak dapat mengajukan permohonan agar memperoleh perpanjangan waktu penyampaian Surat Pemberitahuan Tahunan Pajak Penghasilan. Perpanjangan jangka waktu penyampaian Surat Pemberitahuan Tahunan Pajak Penghasilan hanya dapat diberikan paling lama 6 (enam) bulan.

3. Wajib Pajak berhak untuk membetulkan Surat Pemberitahuan yang telah disampaikan ke KPP. 
Terhadap kekeliruan dalam pengisian Surat Pemberitahuan yang dibuat oleh Wajib Pajak, masih terbuka baginya hak untuk melakukan pembetulan atas kemauan sendiri dalam jangka waktu 2 (dua) tahun sesudah berakhirnya Masa Pajak, Bagian Tahun Pajak atau Tahun Pajak, dengan syarat Direktur Jenderal Pajak belum mulai melakukan tindakan pemeriksaan.

4. Wajib Pajak dapat untuk mengajukan permohonan penundaan dan permohonan untuk mengangsur pembayaran pajak sesuai dengan kemampuannya.

Atas permohonan Wajib Pajak, Direktur Jenderal Pajak dapat memberikan persetujuan untuk mengangsur atau menunda pembayaran pajak yang terutang termasuk kekurangan pembayaran Pajak Penghasilan yang masih harus dibayar dalam Surat Pemberitahuan Tahunan Pajak Penghasilan, meskipun tanggal jatuh tempo pembayaran telah ditentukan. Kelonggaran tersebut diberikan dengan hati-hati untuk paling lama 12 (dua belas) bulan dan terbatas kepada Wajib Pajak yang benar-benar sedang mengalami kesulitan likuiditas.

5. Wajib Pajak berhak untuk mengajukan permohonan penurunan angsuran PPh Pasal 25.

6. Wajib pajak berhak untuk mengajukan permohonan pengembalian kelebihan pembayaran pajak (melakukan restitusi) .

7. Wajib Pajak berhak untuk mengajukan permohonan pembetulan salah tulis atau salah hitung atau kekeliruan yang terdapat dalam Surat Ketetapan Pajak.

Wajib Pajak berhak untuk mengajukan keberatan atas Surat Ketetapan Pajak dan memperoleh kepastian terbitnya keputusan atas surat keberatannya. Wajib Pajak dapat mengajukan keberatan hanya kepada Direktur Jenderal Pajak atas suatu :

a. Surat Ketetapan Pajak Kurang Bayar;

b. Surat Ketetapan Pajak Kurang Bayar Tambahan;

c. Surat Ketetapan Pajak Lebih Bayar;

d. Surat Ketetapan Pajak Nihil;

e. Pemotongan atau pemungutan oleh pihak ketiga berdasarkan ketentuan peraturan perundang-undangan perpajakan.

Keberatan diajukan secara tertulis dalam bahasa Indonesia dengan mengemukakan jumlah pajak yang terutang atau jumlah pajak yang dipotong 
atau dipungut atau jumlah rugi menurut penghitungan Wajib Pajak dengan disertai alasan-alasan yang jelas dalam jangka waktu 3 bulan sejak tanggal surat ketetapan pajak yang diajukan keberatan

9. Wajib Pajak berhak mengajukan banding ke pengadilan pajak atas keputusan keberatan yang diterbitkan oleh Direktur Jenderal Pajak.

10. Wajib Pajak berhak untuk mengajukan permohonan penghapusan atau pengurangan pengenaan sanksi perpajakan serta pembetulan ketetapan pajak yang salah atau keliru.

11. Wajib Pajak berhak memberikan kuasa khusus kepada orang lain yang dipercayainya untuk mewakilinya dalam melaksanakan hak dan kewajiban perpajakannya.

Kewajiban pajak yang harus dilakukan bagi masing-masing wajib pajak berbeda-beda. Dalam tulisan ini akan diuraikan tentang kewajiban pajak bagi wajib pajak orang pribadi, baik yang berstatus sebagai karyawan maupun orang pribadi yang melakukan kegiatan usaha.

\section{WPOP YANG MELAKUKAN KEGIATAN USAHA/ PEKERJAAN BEBAS}

Bagi wajib Pajak Orang Pribadi yang melakukan kegiatan Usaha atau pekerjaan bebas, setelah terdaftar di kantor pelayanan pajak dan memperoleh NPWP maka akan memiliki kewajiban pajak yang harus dilaksanakan. Wajib Pajak Orang Pribadi yang melakukan kegiatan usaha/pekerjaan bebas selaku pemberi kerja selain diwajibkan untuk membayar dan melaporkan pajak yang terutang atas penghasilan yang diterima atau diperolehnyasendiri juga diwajibkan untuk menyetorkan dan melaporkan PPh yang terutang atas penghasilan yang dibayarkan atau terutang kepada karyawannya.

Dalam hal WPOP yang melakukan kegiatan usaha/pekerjaan bebas telah dikukuhkan sebagai Pengusaha kena pajak juga memiliki kewajiban dibidang PPN. Bagi Wajib Pajak Orang Pribadi tertentu yang telah ditunjuk oleh dirjen pajak sebagai pemotong PPh Pasal 23 dan PPh Final pasal 4 (2), juga memiliki kewajiban dibidang PPh 23 dan PPh Final Pasal 4 (2).

Kewajiban yang harus dipenuhi oleh wajib pajak Orang Pribadi yang melakukan kegiatan usaha/pekerjaan bebas setelah memperoleh NPWP adalah sebagai berikut : 
1. Menyampaikan Surat Pemberitahuan Masa (SPT Masa)

Setelah wajib pajak terdaftar di KPP dan memiliki NPWP, maka memiliki kewajiban untuk menyampaikan Surat Pemberitahuan Masa/ bulanan ke kantor pelayanan pajak tempat wajib pajak terdaftar. Jenis SPT Masa yang harus disampaikan oleh wajib pajak Orang Pribadi yang melakukan kegiatan usaha/pekerjaan bebas terdiri dari :

\section{a. SPT Masa PPh Pasal 25}

PPh Pasal 25 merupakan angsuran PPh dalam tahun pajak berjalan yang harus dibayar sendiri oleh Wajib Pajak untuk setiap bulan. Besarnya angsuran PPh Pasal 25 adalah sebesar Pajak Penghasilan yang terutang menurut Surat Pemberitahuan Tahunan Pajak Penghasilan tahun pajak yang lalu, setelah dikurangi dengan PPh yang telah dipotong/dipungut oleh pihak lain dan PPh yang terutang/dibayar diluar negeri yang dapat dikreditkan; dibagi 12 (dua belas).

Bagi wajib pajak yang baru pertama kali memperoleh penghasilan dari usaha atau pekerjaan bebas dalam tahun pajak berjalan (Wajib Pajak baru), besarnya Angsuran PPh Pasal 25 dihitung berdasarkan Pajak Penghasilan yang dihitung berdasarkan penerapan tarif umum atas penghasilan neto sebulan yang disetahunkan, dibagi 12 (dua belas).

\section{b. SPT Masa PPh Pasal 21/26}

PPh pasal 21/26 merupakan PPh yang terutang atas penghasilan berupa gaji, upah, honorarium, tunjangan dan pembayaran lain dengan nama dan dalam bentuk apapun sehubungan dengan pekerjaan, jasa atau kegiatan yang dilakukan oleh wajib pajak orang pribadi. Berdasarkan ketentuan Pasal 21 Undang-undang PPh, PPh Pasal 21 wajib dipotong, disetor dan dilaporkan oleh pemotong pajak, yaitu : pemberi kerja, bendaharawan pemerintah, dana pensiun, badan, perusahaan dan penyelenggara kegiatan.

\section{c. SPT Masa PPN}

Bagi Wajib Pajak yang telah dikukuhkan sebagai Pengusaha Kena Pajak (PKP) diwajibkan untuk memungut Pajak Pertambahan Nilai (PPN) dan 
Pajak atas Penjualan Barang Mewah (PPn BM) serta menyampaikan SPT Masa PPN. Fungsi Surat Pemberitahuan (SPT PPN) adalah sebagai sarana untuk melaporkan dan mempertanggungjawabkan penghitungan jumlah Pajak PPN dan PPn BM yang sebenarnya terutang dan untuk melaporkan tentang : Pengkreditan Pajak Masukan terhadap Pajak Keluaran; Pembayaran atau pelunasan pajak yang telah dilaksanakan sendiri oleh Pengusaha Kena Pajak dan atau melalui pihak lain dalam satu Masa Pajak, yang ditentukan oleh ketentuan peraturan perundang-undangan perpajakan yang berlaku; Ketentuan mengenai PPN diatur dalam Undangundang no 8 tahun 1983 tentang Pajak Pertambahan Nilai Barang dan Jasa dan Pajak Penjualan atas Barang Mewah sebagaimana terakhir telah diubah dengan UU No 18 tahun 2000 beserta peraturan pelaksanaannya.

\section{d. SPT Masa PPh Pasal 23/26}

Direktur Jenderal Pajak dapat menunjuk Wajib Pajak orang pribadi dalam negeri sebagai pemotong Pajak Penghasilan Pasal 23. Wajib Pajak Orang Pribadi tertentu tersebut terdiri dari : Akuntan, Arsitek, Dokter, Notaris, Pejabat Pembuat Akte Tanah (PPAT) kecuali PPAT tersebut adalah Camat, pengacara, dan konsultan, yang melakukan pekerjaan bebas; Orang pribadi yang menjalankan usaha yang menyelenggarakan pembukuan.

Wajib Pajak orang pribadi dalam negeri tertentu tersebut diatas yang telah ditunjuk Dirjen Pajak, akan mendapatkan surat Penunjukan Sebagai Pemotong PPh Pasal 23 dari Kantor Pelayanan Pajak tempat WP terdaftar. WPOP tertentu yang telah ditunjuk sebagai pemotong PPh 23, Wajib memotong PPh Pasal 23 atas pembayaran berupa sewa. Apabila terdapat pembayaran/ pembebanan biaya berupa sewa, maka WPOP tertentu yang telah ditunjuk sebagai pemotong PPh 23 oleh Dirjen pajak, diwajibkan untuk memotong, menyetor dan melaporkan PPh 23 yang terutang atas pembayaran sewa tersebut.

Sesuai dengan ketentuan pasal 26 undang-undang PPh, atas penghasilan berupa:

a. Deviden; 
b. bunga, termasuk premium, diskonto, premi swap dan imbalan sehubungan dengan jaminan pengembalian utang;

c. royalti, sewa, dan penghasilan lain sehubungan dengan penggunaan harta;

d. imbalan sehubungan dengan jasa, pekerjaan, dan kegiatan;

e. hadiah dan penghargaan;

f. pensiun dan pembayaran berkala lainnya ; yang diterima atau diperoleh oleh Wajib Pajak luar negeri selain bentuk usaha tetap di Indonesia, dipotong pajak sebesar 20\% (dua puluh persen) dari jumlah bruto oleh pihak yang wajib membayarkan. Apabila WPOP yang melakukan kegiatan usaha/pekerjaan bebas melakukan transaksi dengan wajib pajak luar negeri sehubungan dengan penghasilan tersebut diatas maka memiliki kewajiban untuk memotong, menyetor dan melaporkan PPh yang terutang atas penghasilan tersebut (PPh Pasal 26). SPT Masa PPh Pasal 23/26 hanya wajib dilaporkan ke KPP apabila terdapat pembayaran yang terutang PPh Pasal 23/26. Dengan demikian tidak terdapat SPT Masa PPh pasal 23/26 Nihil.

e. SPT Masa PPh Final pasal 4 (2)

1) PPh final atas penghasilan yang diterima/diperoleh oleh wajib pajak. Bagi Wajib Pajak Orang Pribadi yang melakukan kegiatan usaha atau pekerjaan bebas yang memperoleh penghasilan yang merupakan obyek PPh final, maka diwajibkan untuk membayar dan melaporkan PPh final pasal 4 (2) yang tertuang atas penghasilan tersebut. Jenis penghasilan lain yang merupakan obyek PPh final dan pembayaran PPh-nya wajib dilakukan sendiri oleh penerima penghasilan (Wajib pajak) adalah sebagai berikut : -Penghasilan dari pengalihan hak atas tanah dan/atau bangunan; WPOP yang menerima/memperoleh penghasilan dari transaksi pengalihan hak atas tanah dan/atau bangunan diwajibkan membayar PPh final pasal 4 (2). Besarnya PPh yang terutang atas transaksi pengalihan hak atas tanah dan/atau bangunan ini adalah sebesar 5\% dari nilai yang tertinggi antara nilai pengalihan (nilai transaksi) dengan nilai NJOP. 
- Penghasilan dari persewaan tanah dan/atau bangunan;Penghasilan yang diterima/diperoleh oleh WPOP dari kegiatan persewaan tanah dan atau bangunan juga merupakan obyek PPh final pasal 4 (2). Dalam hal penyewa adalah bukan pemotong pajak, maka PPh yang terutang atas penghasilan dari transaksi persewaan tanah dan atau bangunan wajib dibayar sendiri oleh penerima penghasilan. Besarnya PPh yang terutang atas transaksi ini adalah sebesar $10 \%$ dari jumlah bruto nilai persewaan.

Penghasilan dari Usaha Jasa Konstruksi;

Apabila pemakai jasa bukan merupakan pemotong $\mathrm{PPh}$, atas Penghasilan yang diterima/diperoleh oleh WPOP dari kegiatan Jasa Konstruksi, PPh yang terutang atas penghasilan tersebut wajib dibayar sendiri oleh wajib pajak. Namun apabila pemakai jasa merupakan pemotong pajak, maka PPh yang terutang atas kegiatan ini pelunasannya dilakukan melalui pemotongan oleh pemakai jasa. Pemotong pajak (Pemakai jasa) wajib memberikan bukti potong. Besarnya PPh final pasal 4 (2) yang terutang atas penghasilan dari kegiatan jasa konstruksi adalah sbb : 4\% (empat persen) darila) Jasa Perencanaan Konstruksi jumlah bruto; 2\% (dua persen) dari(b) Jasa Pelaksanaan Konstruksi jumlah bruto; 4\% (empat persen) dari(c) Jasa Pengawasan Konstruksi jumlah bruto.

2) PPh final atas penghasilan yang terutang/dibayarkan kepada pihak lain.

Dirjen Pajak dapat menunjuk Wajib pajak Orang Pribadi tertentu sebagai pemotong PPh Final Pasal 4 (2) atas transaksi persewaan Tanah dan atau bangunan.Wajib Pajak Orang Pribadi tertentu yang dapat ditunjuk sebagai pemotong PPh atas transaksi persewaan tanah dan atau bangunan oleh DJP adalah:

- Akuntan, arsitek, dokter, Notaris, Pejabat Pembuat Akte Tanah (PPAT) kecuali PPAT tersebut adalah Camat, pengacara, dan konsultan, yang melakukan pekerjaan bebas yang telah terdaftar sebagai Wajib Pajak Dalam Negeri, 
- Orang pribadi yang menjalankan usaha yang menyelenggarakan pembukuan yang telah terdaftar sebagai Wajib Pajak dalam negeri.

WPOP tertentu yang telah mendapat surat penunjukan sebagai pemotong Pajak atas penghasilan dari persewaan tanah dan atau bangunan dari KPP tempat WP terdaftar memiliki kewajiban untuk memotong, menyetorkan dan melaporkan PPh final atas penghasilan dari transaksi persewaan tanah dan atau bangunan yang dibayarkan atau terutang kepada pihak lain. SPT Masa PPh Final hanya wajib dilaporkan oleh wajib pajak apabila terdapat transaksi yang berhubungan dengan obyek PPh final, sehingga tidak ada SPT Masa PPh Final Nihil.

2. Menyampaikan Surat Pemberitahuan Tahunan (SPT Tahunan)

Setelah berakhirnya tahun pajak, Wajib pajak diwajibkan untuk menyampaikan SPT Tahunan (SPT Tahunan PPh Orang Pribadi - SPT 1770). Fungsi Surat Pemberitahuan (SPT Tahunan) bagi Wajib Pajak adalah sebagai sarana untuk melaporkan dan mempertanggungjawabkan penghitungan jumlah pajak yang sebenarnya terutang dan untuk melaporkan tentang:

a. Pembayaran atau pelunasan pajak yang telah dilaksanakan sendiri dan atau melalui pemotongan atau pemungutan pihak lain dalam 1 (satu) Tahun Pajak atau Bagian Tahun Pajak;

b. Penghasilan yang merupakan objek pajak dan atau bukan objek pajak;

c. Harta dan kewajiban;

WPOP YANG TIDAK MELAKUKAN KEGIATAN USAHA/ PEKERJAAN BEBAS (WPOP KARYAWAN)

WPOP Karyawan yang hanya memperoleh penghasilan dari satu pemberi kerja.

Wajib Pajak Orang Pribadi yang tidak melakukan kegiatan usaha atau pekerjaan bebas (berstatus sebagai karyawan) dan hanya bekerja pada satu pemberi kerja tidak memiliki kewajiban untuk membayar pajak sendiri setiap bulan atas penghasilan yang diterima/ diperoleh sehubungan dengan pekerjaan. WP Orang Pribadi ini juga tidak memiliki kewajiban untuk membuat laporan (Surat Pemberitahuan Masa) ke Kantor Pelayanan Pajak setiap bulan. 
Perusahaan tempat wajib pajak bekerja (pemberi kerja) memiliki kewajiban untuk memotong pajak atas penghasilan sehubungan pekerjaan yang dibayarkan/terutang kepada karyawannya setiap bulan dan menyetorkannya ke Kas Negara serta melaporkannya ke kantor pelayanan pajak setempat. Oleh karena itu gaji yang diterima oleh wajib pajak orang pribadi yang berstatus sebagai karyawan adalah gaji bersih setelah dipotong pajak penghasilan. Pajak yang terutang atas Penghasilan sehubungan dengan pekerjaan dikenal dengan istilah PPh Pasal 21.

Kewajiban yang harus dilakukan oleh WPOP yang berstatus sebagai karyawan adalah menyampaikan laporan tahunan (menyampaikan SPT Tahunan PPh Orang Pribadi) dengan formulir yang telah disediakan (Form 1770S). Apabila wajib pajak orang pribadi ini tidak menerima/memperoleh penghasilan lain selain penghasilan yang diperoleh dari satu pemberi kerja, maka pada saat menyampaikan SPT Tahunan tidak akan terdapat PPh yang kurang dibayar.

\section{WPOP Karyawan yang memperoleh penghasilan lain yang bukan obyek PPh} Final.

Bagi Wajib Pajak Orang Pribadi yang tidak melakukan kegiatan usaha atau pekerjaan bebas (WPOP Karyawan) yang memperoleh penghasilan lain selain dari satu pemberi kerja, baik karena bekerja pada lebih dari satu pemberi kerja maupun memiliki penghasilan lain selain dari pekerjaan dan penghasilan lain tsb bukan merupakan obyek PPh final, maka selain diwajibkan untuk melaporkan SPT Tahunan (SPT 1770-S) juga memiliki kewajiban untuk membayar dan melaporkan PPh pasal 25 setiap bulan.

Besarnya PPh Pasal 25 yang harus dibayar oleh wajib pajak dihitung berdasarkan PPh yang terutang dalam SPT Tahunan tahun sebelumnya setelah dikurangi dengan pemotongan yang dilakukan pihak lain yang dapat dikreditkan dan dibagi 12 (dua belas).

c. WPOP Karyawan yang memperoleh penghasilan lain yang merupakan obyek PPh Final.

Bagi Wajib Pajak Orang Pribadi yang tidak melakukan kegiatan usaha atau pekerjaan bebas (WPOP Karyawan) yang memperoleh penghasilan lain 
selain dari satu pemberi kerja, dan memiliki penghasilan lain yang merupakan obyek PPh final, maka selain diwajibkan untuk melaporkan SPT Tahunan (SPT 1770-S) juga memiliki kewajiban untuk membayar dan melaporkan PPh final pasal 4 (2).

Jenis penghasilan lain yang merupakan obyek PPh final dan pembayaran PPh-nya wajib dilakukan sendiri oleh penerima penghasilan (wajib pajak) adalah sebagai berikut :

\section{Penghasilan dari pengalihan hak atas tanah dan/atau bangunan;}

WPOP Karyawan yang menerima/memperoleh penghasilan dari transaksi pengalihan hak atas tanah dan/atau bangunan diwajibkan membayar PPh final pasal 4 (2). Besarnya PPh yang terutang atas transaksi pegalihan hak atas tanah dan/atau bangunan ini adalah sebesar $5 \%$ dari nilai yang tertinggi antara nilai pengalihan (nilai transaksi) dengan nilai NJOP.

\section{Penghasilan dari persewaan tanah dan/atau bangunan;}

Penghasilan yang dierima/diperoleh oleh WPOP karyawan dari kegiatan persewaan tanah dan atau bangunan juga merupakan obyek PPh final pasal 4 (2). Dalam hal penyewa adalah bukan pemotong pajak, maka PPh yang terutang atas penghasilan dari transaksi persewaan tanah dan atau bangunan wajib dibayar sendiri oleh penerima penghasilan. Besarnya PPh yang terutang atas transaksi ini adalah sebesar $10 \%$ dari jumlah bruto nilai persewaan. Apabila penyewa adalah pemotong pajak (i.e. WP Badan), maka pelunasan PPh final atas transaksi ini dilakukan melalui pemotongan oleh pihak penyewa. Pemotong pajak (penyewa) wajib memberikan bukti pemotongan (Bukti Potong PPh Final pasal 4 (2)) kepada wajib pajak (penerima penghasilan).

\section{Penghasilan dari Usaha Jasa Konstruksi ;}

Penghasilan yang diterima/diperoleh oleh WPOP Karyawan dari kegiatan Jasa Konstruksi (sebagai usaha sampingan misalnya), Apabila pemakai jasa bukan merupakan pemotong pajak, maka PPh-nya wajib dibayar sendiri oleh wajib pajak. Namun apabila pemakai jasa merupakan pemotong pajak, maka PPh yang terutang atas kegiatan ini pelunasannya dilakukan melalui 
pemotongan oleh pemakai jasa. Pemotong pajak (Pemakai jasa) wajib memberikan bukti potong. Besarnya PPh final pasal 4 (2) yang terutang atas penghasilan dari kegiatan jasa konstruksi adalah sbb :

a. Jasa Perencanaan Konstruksi ==> 4\% (empat persen) dari jumlah bruto;

b. Jasa Pelaksanaan Konstruksi $==>2 \%$ (dua persen) dari jumlah bruto;

c. Jasa Pengawasan Konstruksi ==> 4\% (empat persen) dari jumlah bruto.

\section{DAMPAK KETERLAMBATAN KEPEMILIKAN NPWP PRIBADI}

Saat ini ruang bagi orang pribadi untuk lepas dari kewajiban ber- NPWP dapat dikatakan semakin sempit. Karena hampir semua sektor dipagari oleh pemerintah dengan prasyarat NPWP. Selain itu pemerintah juga memberikan diskriminasi pengenaan pajak antara orang pribadi yang berNPWP dengan yang tidak, yang dapat dijelaskan pada tabel 1

Tabel 1

Diskriminasi Pengenaan Pajak Untuk Orang Pribadi

\begin{tabular}{|c|c|c|}
\hline Aspek Pemajakan & Ber NPWP & Tidak BerNPWP \\
\hline $\begin{array}{l}\text { Witholding } \text { Tax (WHT) } \\
\text { PPh pasal } 21\end{array}$ & Tarif normal & $\begin{array}{l}20 \% \text { lebih tinggi dari tarif } \\
\text { normal }\end{array}$ \\
\hline WHT PPh pasal 22 & Tarif normal & $\begin{array}{l}\text { 100\% lebih tinggi dari } \\
\text { tarif normal }\end{array}$ \\
\hline WHT PPh pasal 23 & Tarif normal & $\begin{array}{l}100 \% \text { lebih tinggi dari } \\
\text { tarif normal }\end{array}$ \\
\hline Fiskal Luar Negeri & Bebas FLN & $\begin{array}{l}\text { Dikenai Fiskal Luar } \\
\text { Negeri: } \\
\text { - Perjalanan udara } \\
\text { Rp.2.500.000,- } \\
\text { - Perjalanan laut } \\
\text { Rp.1.000.000,- }\end{array}$ \\
\hline
\end{tabular}

Sumber: Indonesia Tax Review, 2009 
Ketentuan mengenai pemotongan PPh pasal 21 dengan menggunakan tarif 20\% lebih tinggi bagi orang pribadi yang tidak berNPWP diatur dalam pasal 21 ayat (5 a) UU no. 36 Tahun 2008 jo pasal 20 PMK No.252/PMK.03/2008. Seperti kita ketahui, penghitungan PPh pasal 21 menggunakan tarif progresif PPh yang diatur dalam ketentuan pasal 17 ayat (1) huruf a UU PPh. Dengan demikian tarif dapat diikhtisarkan pada tabel 2 sebagai berikut:

Tabel 2

Tarif Pasal 17 UU PPH untuk menghitung PPh pasal 21

\begin{tabular}{|l|l|l|}
\hline Lapisan Penghasilan Kena Pajak & Tarif Pajak & Tarif Non NPWP \\
\hline Sampai dengan Rp.50.000.000,00 & $5 \%$ & $120 \% \times 5 \%=6 \%$ \\
\hline $\begin{array}{l}\text { Diatas Rp.50.000.000,00 s/d } \\
\text { Rp.250.000.000,00 }\end{array}$ & $15 \%$ & $120 \% \times 15 \%=18 \%$ \\
\hline $\begin{array}{l}\text { Diatas Rp.250.000.000,00 s/d } \\
\text { Rp.500.000.000,00 }\end{array}$ & $25 \%$ & $120 \% \times 25 \%=30 \%$ \\
\hline Diatas Rp.500.000.000,00 & $30 \%$ & $120 \% \times 30 \%=36 \%$ \\
\hline
\end{tabular}

Sumber: Indonesia Tax Review, 2009

Lebih lanjut dalam pasal 20 ayat (3) PMK No. 252/PMK.03/2008 diperjelas bahwa pengenaan tarif $20 \%$ lebih tinggi untuk orang pribadi yang belum memiliki NPWP hanya diterapkan untuk PPh pasal 21 yang bersifat tidak final. Dalam konteks pemotongan PPh pasal 21, bila orang pribadi khusus untuk pegawai tetap terlambat mendaftarkan diri untuk memperoleh NPWP maka hal ini dapat menimbulkan lebih bayar dalam penghitungan PPh pasal 21 dimasa pajak terakhirnya, karena penghitungan PPh pasal 21 untuk pegawai tetap masih menggunakan prinsip estimasi dan realisasi. Penghitungan estimasi PPh 21 secara estimasi dilakukan di setiap masa kecuali pada masa pajak terakhir (masa Desember atau masa dimana karyawan berhenti bekerja) yang menggunakan penghitungan realisasi.

Bagi orang pribadi yang bukan pegawai, khususnya orang pribadi bukan pegawai sebagaimana dimaksud dalam ketentuan Pasal 9 ayat (1) huruf a angka 4 dampak dari tidak memiliki NPWP tak hanya akan dikenai tarif $20 \%$ lebih 
tinggi. Orang pribadi tersebut akan kehilangan hak untuk memperhitungkan PTKP. Orang pribadi bukan pegawai yang dimaksud dalam pasal 9 ayat (1) huruf a angka 4 adalah distributor multi level marketing (direct selling), petugas dinas luar asuransi yang tidak berstatus pegawai, penjaja barang dagangan yang tidak berstatus pegawai, dan atau penerima penghasilan bukan pegawai lainnya yang menerima penghasilan dari pemotong PPh pasal 21 secara berkesinambungan dalam 1 (satu) tahun kalender.

Sesuai dengan ketentuan pasal 15 ayat (2) PMK Nomor: 252/PMK.03/2009 PPh pasal 21 atas penerima penghasilan orang pribadi sebagaimana dimaksud dalam pasal 9 ayat (1) huruf a angka 4 adalah tarif pasal 17 ayat (1) huruf a UU PPh atas jumlah kumulatif penghasilan kena pajak. Dalam hal ini penghasilan kena pajak merupakan jumlah penghasilan bruto dikurangi PTKP.

Dalam ketentuan pasal 12 ayat (1) PMK No.252/PMK.03/2009 disebutkan bahwa penerima penghasilan bukan pegawai sebagaimana yang dimaksud dalam pasal 9 ayat (1) huruf a angka 4 dapat memperoleh pengurangan PTKP sepanjang yang bersangkutan telah mempunyai NPWP dan hanya memperoleh pengurangan PTKP sepanjang yang bersangkutan telah mempunyai NPWP dan hanya memperoleh penghasilan dari hubungan kerja dengan pemotong pajak serta tidak memperoleh penghasilan lainnya. Sehingga sesuai dengan ketentuan tersebut bukan pegawai sebagaimana yang dimaksud dalam pasal 9 ayat (1) huruf a angka 4 yang tidak ber NPWP, maka tidak berhak memperoleh pengurangan PTKP, adapun penghitungan PPh pasal 21 diterapkan atas tarif $20 \%$ lebih tinggi dari tariff pasal 17 UU PPh atas penghasilan bruto.

\section{KESIMPULAN}

Kewajiban ber NPWP sesungguhnya merupakan kewajiban setiap orang pribadi, baik orang pribadi yang melakukan kegiatan usaha atau pekerjaan bebas ataupun yang berstatus pegawai. Berdasarkan undang-undang no 6 tahun 1983 tentang ketentuan umum dan tatacara perpajakan, sebagaimana terakhir telah diubah dengan undang-undang no 28 tahun 2007, terdapat kewajiban wajib pajak sebagai berikut: Mendaftarkan diri ke KPP untuk memperoleh NPWP, Wajib melaporkan usahanya untuk dikukuhkan menjadi Pengusaha Kena Pajak, 
Mengambil sendiri Surat Pemberitahuan di tempat yang ditetapkan oleh Direktur Jenderal Pajak, Wajib Pajak wajib mengisi dan menyampaikan Surat Pemberitahuan dengan benar, lengkap, jelas, dan menandatanganinya, Wajib membayar atau menyetor pajak yang terutang di kas negara, Wajib menyelenggarakan pembukuan atau pencatatan, Dalam hal terjadi pemeriksaan pajak, Wajib Pajak wajib memperlihatkan dan atau meminjamkan buku atau catatan, dokumen yang menjadi dasarnya dan dokumen lain yang berhubungan dengan penghasilan yang diperoleh, kegiatan usaha, pekerjaan bebas Wajib Pajak, atau objek yang terutang pajak; Memberikan kesempatan untuk memasuki tempat atau ruang yang dipandang perlu dan memberi bantuan guna kelancaran pemeriksaan; Memberikan keterangan yang diperlukan.

Adapun hak wajib pajak adalah wajib pajak berhak untuk menerima tanda bukti pelaporan SPT, Wajib Pajak berhak untuk mengajukan permohonan penundaan penyampaian SPT, Wajib Pajak berhak untuk membetulkan Surat Pemberitahuan yang telah disampaikan ke KPP, Wajib Pajak dapat untuk mengajukan permohonan penundaan dan permohonan untuk mengangsur pembayaran pajak sesuai dengan kemampuannya, Wajib Pajak berhak untuk mengajukan permohonan penurunan angsuran PPh Pasal 25, Wajib pajak berhak untuk mengajukan permohonan pengembalian kelebihan pembayaran pajak (melakukan restitusi), Wajib Pajak berhak untuk mengajukan permohonan pembetulan salah tulis atau salah hitung atau kekeliruan yang terdapat dalam Surat Ketetapan Pajak, Wajib Pajak berhak untuk mengajukan keberatan atas Surat Ketetapan Pajak dan memperoleh kepastian terbitnya keputusan atas surat keberatannya, Wajib Pajak berhak mengajukan banding ke pengadilan pajak atas keputusan keberatan yang diterbitkan oleh Direktur Jenderal Pajak, Wajib Pajak berhak untuk mengajukan permohonan penghapusan atau pengurangan pengenaan sanksi perpajakan serta pembetulan ketetapan pajak yang salah atau keliru, Wajib Pajak berhak memberikan kuasa khusus kepada orang lain yang dipercayainya untuk mewakilinya dalam melaksanakan hak dan kewajiban perpajakannya.

Sedangkan dampak pada orang pribadi adalah adanya diskriminasi oleh pemerintah mengenai pengenaan pajak antara orang pribadi yang berNPWP 
dengan yang tidak, yaitu untuk aspek pemajakan Witholding Tax (WHT) PPh pasal 21 bagi orang pribadi yang ber-NPWP tariff normal sesuai pasal17, sedang yang tidak ber-NPWP tarif $20 \%$ lebih tinggi dari tarif normal. Aspek pemajakan WHT PPh pasal 22 bagi orang pribadi yang ber-NPWP tarif normal, sedang yang tidak ber-NPWP tarif $100 \%$ lebih tinggi dari tarif normal. Aspek pemajakan WHT PPh pasal 23 bagi orang pribadi yang ber-NPWP tarif normal, sedang yang tidak ber-NPWP tarif $100 \%$ lebih tinggi dari tarif normal. Aspek pemajakan Fiskal Luar Negeri bagi orang pribadi yang ber-NPWP bebes Fiskal Luar Negeri, sedang yang tidak ber-NPWP dikenai Fiskal Luar Negeri. 


\section{DAFTAR PUSTAKA}

Budianto, Triyani. Ketika Kita harus Mempunyai NPWP. www.triyani.co.id

Gunadi,. 2001. Panduan Komprehensif Pajak penghasilan. PT Multi Utama Consultindo, Jakarta

Indonesian Tax Review, 2009. Dampak Telat Ber-NPWP. Majalah Dwi Mingguan Volume II/Edisi 03/2009

Mardiasmo. 2006. Perpajakan Edisi Revisi . Penerbit Andi Offset, Yogyakarta

Republik Indonesia, Undang-Undang Nomor 6 Tahun 1983 tentang Ketentuan Umum dan Tata Cara Perpajakan.

Republik Indonesia, Undang-Undang Nomor 7 Tahun 1983 tentang Pajak Penghasilan.

Republik Indonesia, Undang-Undang Nomor 7 Tahun 1991 tentang Perubahan Atas Undang-Undang Nomor 7 Tahun 1983 tentang Pajak Penghasilan.

Republik Indonesia, Undang-Undang Nomor 9 Tahun 1994 tentang Perubahan Atas Undang-Undang Nomor 6 Tahun 1983 tentang Ketentuan Umum dan Tata Cara Perpajakan.

Republik Indonesia, Undang-Undang Nomor 10 Tahun 1994 tentang Perubahan Atas Undang-Undang Nomor 7 Tahun 1983 tentang Pajak Penghasilan sebagaimana telah diubah dengan Undang-Undang Nomor 7 Tahun 1991.

Republik Indonesia, Undang-Undang Nomor 16 Tahun 2000 tentang Perubahan Kedua atas Undang-Undang Nomor 6 Tahun 1983 tentang Ketentuan Umum dan Tata Cara Perpajakan.

Republik Indonesia, Undang-Undang Nomor 17 Tahun 2000 tentang Perubahan Ketiga atas Undang-Undang Nomor 7 Tahun 1983 tentang Pajak Penghasilan.

Republik Indonesia, Undang-undang No. 28 tahun 2007 tentang perubahan ketiga atas Undang-Undang Nomor 6 Tahun 1983 tentang Ketentuan Umum dan tatacara Perpajakan

Republik Indonesia, Undang-undang No.36 tahun 2008 tentang Perubahan Keempat atas Undang-Undang Nomor 7 Tahun 1983 tentang Pajak penghasilan

Republik Indonesia, Penjelasan dan Peraturan yang berkaitan dengan UndangUndang Perpajakan tersebut. 
Republik Indonesia, Peraturan Pemerintah, Keputusan Presiden, Keputusan Menteri Keuangan, Keputusan Direktur Jenderal Pajak, dan Surat Edaran Direktur Jenderal Pajak yang berkaitan dengan Undang-Undang Perpajakan tersebut. 